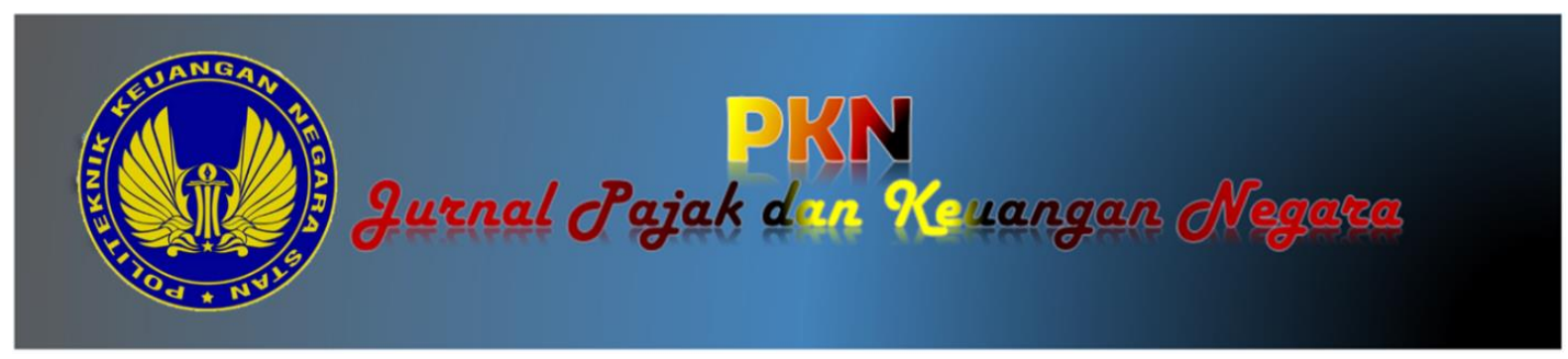

\title{
EVALUASI PENILAIAN UNTUK PEMERIKSAAN TERHADAP NILAI WAJAR PASAR DI MASA PANDEMI COVID 19
}

\author{
Tri Hastowibowo \\ Direktorat Jenderal Pajak \\ Agus Bandiyono \\ Politeknik Keuangan Negara STAN
}

Alamat Korespondensi: agusbandiyono@pknstan.ac.id

\section{INFORMASI ARTIKEL}

Diterima Pertama

[09 07 2021]

Dinyatakan Diterima

[24 08 2021]

KATA KUNCI:

Nilai Pasar Wajar; Penilaian; Pemeriksaan Pajak; PPh Final

KLASIFIKASI JEL:

$\mathrm{H} 210$

\section{ABSTRACT}

The transfer of rights for land and/or building is one of the transactions subjects to final income tax. The transaction must be reported to Tax Service Office for validation and observation, formally or materially. However, taxpayers often submitted the false transaction value. On that matter, the assessment for transfer of rights is required. The purpose is to determine the fair market value of the valuation object. This research has the intention to evaluate the process of assessment in the framework of examination of the fair market value for the transfer of rights to land and/or building in KPP Pratama Metro, using descriptive research methods with literature study methods and field study methods in the form of interviews and direct observation. The results conclude whether the implementation of the assessment process has been in accordance with the applicable regulation or not.

\section{ABSTRAK}

Pengalihan hak atas tanah dan/atau bangunan merupakan salah satu transaksi yang dikenakan pajak penghasilan bersifat final. Transaksi tersebut harus dilaporkan ke Kantor Pelayanan Pajak guna dilakukan validasi dan diteliti baik secara formil maupun material. Namun, tidak jarang Wajib Pajak mencantumkan nilai pengalihan yang tidak seharusnya. Atas dasar hal tersebut, maka perlu dilakukan penilaian atas pengalihan tersebut. Tujuan penelitian ini adalah untuk mengevaluasi proses pelaksanaan penilaian dalam rangka pemeriksaan terhadap nilai wajar pasar atas pengalihan hak atas tanah dan/atau bangunan di Kantor Pelayanan Pajak Pratama Metro, dengan menggunakan metode penelitian deskriptif dengan metode studi kepustakaan dan metode studi lapangan berupa wawancara dan pengamatan secara langsung. Hasil dari peneltian ini bahwa pelaksanaan proses penilaian telah sesuai dengan ketentuan yang berlaku. Serta saat kondisi pandemi COVID19 tidak berbeda dengan proses penilaian saat kondisi sebelum terjadi pandemi COVID-19. Perbedaan yang terjadi terletak pada penerapan protokol kesehatan saat petugas akan melakukan kunjungan ke lapangan guna mengumpulkan data terkait dengan objek penilaian. 


\section{PENDAHULUAN}

\subsection{Latar Belakang}

Ketika seseorang menjual tanah atau rumah yang mereka miliki, maka terdapat beberapa jenis pajak yang harus dibayarkan. Setelah harga jual disepakati oleh penjual dan pembeli, maka harga tersebut menjadi dasar nilai yang akan menjadi perhitungan pajaknya. Dalam pelaksanaan sistem self assessment, masih terdapat banyak Wajib Pajak yang memanfaatkan celah hukum untuk mengurangi pajak yang seharusnya dibayar. Ellryz \& Suryandono (2019) mengatakan bahwa tidak sedikit Wajib Pajak enggan membayar pajak dengan nominal yang seharusnya atau bahkan tidak membayar pajaknya sama sekali dengan berbagai macam cara seperti yang diungkapkan oleh Irma Devita (2021) bahwa maraknya pemalsuan dalam pembayaran pajak yang dibayarkan sendiri oleh para klien Notaris atau PPAT. Pemalsuan tersebut dilakukan dalam bentuk pemalsuan bukti pembayaran, pemalsuan bukti validasi atas pembayaran Pajak Penghasilan (PPh) maupun Bea Pengalihan Hak Atas Tanah dan Bangunan (BPHTB) hingga pemalsuan bukti pembayaran Pajak Bumi dan Bangunan (PBB).

Pajak sendiri merupakan kontribusi wajib kepada negara yang terutang oleh orang pribadi atau badan yang bersifat memaksa berdasarkan Undang-Undang, dengan tidak mendapatkan imbalan secara langsung dan digunakan untuk keperluan negara bagi sebesar-besarnya kemakmuran rakyat sebagaimana tertulis dalam Undang-Undang Nomor 28 Tahun 2007 tentang Perubahan Ketiga Atas Undang-Undang Nomor 6 Tahun 1983 Tentang Ketentuan Umum dan Tata Cara Perpajakan. Salah satu pajak yang dikenakan terhadap subjek pajak adalah pajak penghasilan. Kosasih (2019) mengatakan bahwa berdasarkan sifat pemotongan atau pemungutannya, pajak penghasilan (PPh) dibedakan menjadi dua yakni pajak penghasilan final yang selanjutnya disebut PPh Final dan pajak penghasilan tidak final yang selanjutnya disebut PPh Tidak Final. Salah satu objek PPh Final yaitu penghasilan dari pengalihan hak atas tanah dan/atau bangunan. Peraturan Pemerintah Nomor 34 Tahun 2016 Tentang Pajak Penghasilan Atas Penghasilan Dari Pengalihan Hak Atas Tanah dan/atau Bangunan, dan Perjanjian Pengikatan Jual Beli Atas Tanah dan/atau Bangunan Beserta Perubahannya mengatur tentang penghasilan yang diterima oleh orang pribadi atau badan dari pengalihan hak atas tanah dan/atau bangunan.

Terdapat dua penelitian yang dilakukan oleh Direktorat Jenderal Pajak yaitu penelitian formal oleh KPP yang wilayah kerjanya meliputi lokasi tanah dan/atau bangunan dan penelitian material dilakukan oleh KPP tempat Wajib Pajak terdaftar atau KPP yang wilayah kerjanya meliputi lokasi tanah dan/atau bangunan bagi orang pribadi yang belum memiliki Nomor Pokok Wajib Pajak (NPWP). Berdasarkan Wicaksono (2018) menerangkan bahwa penelitian formal di KPP dilakukan oleh Seksi Pelayanan yang mana dokumen permohonan dari Wajib Pajak divalidasi oleh petugas untuk diteliti kelengkapan dan kesesuaian dokumennya. Sehubungan dengan hal itu, Riza M.R.A. (2020) menyatakan bahwa fungsi dari validasi pajak adalah untuk memastikan bahwa bukti Surat Setoran Pajak (SSP) tersebut asli, karena juga ada juga SSP yang palsu dan untuk memastikan bahwa penghitungan telah dilakukan dengan benar.

Penelitian material yang juga dilakukan oleh Seksi Pelayanan KPP bertujuan guna memastikan kebenaran jumlah pajak yang terutang. Penelitian tersebut dilakukan dengan cara meneliti kebenaran nilai pengalihan hak atas tanah dan/atau bangunan yang terjadi. Pada kondisi yang sering terjadi memang sering ditemukan nilai pengalihan yang tidak wajar atau seharusnya, sehingga penelitian material ini harus dilakukan. Wajib pajak tidak mencantumkan nilai pengalihan yang sebenarnya dengan tujuan agar pajak terutang yang dibayarkan menjadi lebih rendah dari yang seharusnya. Sehingga perlu dilakukan penilaian atas nilai pengalihan yang terindikasi memiliki nilai yang tidak wajar.

KPP Pratama Metro merupakan salah satu instansi vertikal yang berada dibawah unit eselon I yaitu Direktorat Jenderal Pajak. KPP Pratama Metro memiliki tugas memberikan pelayanan perpajakan kepada wajib pajak yang berada di wilayah kerja mereka. Salah satu layanan yang diberikan adalah melayani permohonan penelitian bukti pemenuhan kewajiban penyetoran Pajak Penghasilan dari pengalihan hak atas tanah dan/atau bangunan. Terdapat banyak permohonan penelitian yang diterima oleh KPP Pratama Metro dan terdapat 
beberapa transaksi pengalihan hak atas tanah dan/atau bangunan yang terindikasi memiliki nilai pengalihan yang tidak sewajarnya.

Tabel 1-1 Pengalihan Hak Atas Tanah dan/atau Bangunan yang memiliki nilai pengalihan yang tidak sewajarnya

\begin{tabular}{|c|c|c|c|c|c|c}
\hline No & Pembeli & Alamat Objek Pajak & $\begin{array}{c}\text { Luas } \\
\text { Tanah }\end{array}$ & $\begin{array}{c}\text { Luas } \\
\text { Bangunan }\end{array}$ & $\begin{array}{c}\text { Nilai Pada } \\
\text { Laporan PPAT }\end{array}$ & $\begin{array}{c}\text { Nilai } \\
\text { Perhit }\end{array}$ \\
\hline 1 & Wajib Pajak 1 Jalan Sutan Dumas & 90 & 36 & Rp25.000.000 & Rp \\
\hline 2 & Wajib Pajak 2 & Jalan Sutan Dumas & 90 & 36 & Rp90.000.000 & Rp \\
\hline 3 & Wajib Pajak 3 & Jalan Sutan Dumas & 90 & 36 & Rp25.000.000 & Rp \\
\hline
\end{tabular}

Sumber: data diolah dari KPP Pratama

\section{Metro}

Nilai pengalihan yang tidak seharusnya tersebut membutuhkan koreksi yang dapat dilakukan oleh Petugas Penilai Pajak di KPP Pratama. Dalam kondisi pandemi COVID-19 tentunya proses penilaian akan sedikit berbeda dengan sebelum terjadinya pandemi COVID-19.

Ali Tranghanda (2021), CEO dan founder Indonesia Property Watch menyatakan bahwa . pergerakan pasar properti sejak pandemi terjadi di awal 2020 memperlihatkan pola yang tidak stabil, yaitu bahwa naik turun pasar properti masih menunjukkan kondisi jangka pendek dan belum membentuk pola jangka panjang yang stabil. Terlihat mulai terjadi pertumbuhan tipis sejak semester kedua tahun lalu, tetapi pasar properti masih rentan terhadap penurunan yang lebih dalam lagi.

Pencarian data yang biasanya dapat dengan mudah dilakukan dengan melakukan tinjaun ke lokasi objek penilaian menjadi terhambat karena diharuskan mematuhi protokol kesehatan yang ada. Terdapat beberapa hal yang harus diperhatikan oleh Petugas Penilai Pajak sebelum melakukan kunjungan ke lapangan yaitu seperti memperhitungkan tingkat kerawanan penyebaran virus COVID-19 di lokasi objek penilaian, memperhitungkan potensi penerimaan pajak atas objek penilaian dan melakukan komunikasi terlebih dahulu kepada Wajib Pajak.

Berdasarkan hal tersebut, penulis melakukan evaluasi terkait bagaimana proses penilaian atas pengalihan hak atas tanah dan/atau bangunan yang dianggap memiliki nilai yang tidak sewajarnya. Fokus pembahasan dalam penelitian ini adalah mengenai pelaksanaan proses penilaian dalam rangka pemeriksaan terhadap nilai wajar pasar atas pengalihan hak atas tanah dan/atau bangunan yang terjadi di KPP Pratama Metro.

\subsection{Tujuan}

Adapun tujuan yang ingin dicapai dalam penyusunan penulisan ini diantaranya :

1) Untuk mengevaluasi pelaksanaan proses penilaian dalam rangka pemeriksaan terhadap nilai wajar pasar; 2) Untuk mengevaluasi perbedaan pelaksanaan proses penilaian saat pandemi COVID-19; 3) Untuk mengidentifikasi permasalahan serta kendala yang dihadapi dalam pelaksanaan proses penilaian tersebut sebelum terjadi pandemi COVID-19; 4) Untuk mengidentifikasi permasalahan serta kendala yang dihadapi dalam pelaksanaan proses penilaian saat pandemic COVID-19.

\section{TINJAUAN PUSTAKA}

\subsection{Teori Umum Perpajakan}

\subsubsection{Pengertian Pajak}

Dalam Undang-Undang Nomor 28 Tahun 2007 tentang Perubahan Ketiga Atas UndangUndang Nomor 6 Tahun 1983 Tentang Ketentuan Umum dan Tata Cara Perpajakan yang dimaksud dengan pajak adalah kontribusi wajib kepada negara yang terutang oleh orang pribadi atau badan yang bersifat memaksa berdasarkan Undang-Undang, dengan tidak mendapatkan imbalan secara langsung dan digunakan untuk keperluan negara bagi sebesar-besarnya kemakmuran rakyat. Selain pengertian diatas, terdapat juga beberapa pengertian pajak menurut para ahli. Salah satunya pengertian pajak menurut Soemitro (dalam Ferbiana, 2016) adalah iuran rakyat kepada kas negara berdasarkan undang-undang (yang dapat dipaksakan) dengan tidak mendapatkan jasa timbal balik (kontraprestasi) yang langsgung yang dapat ditunjukan dan yang digunakan untuk membayar pengeluaran umum

\subsubsection{Pajak Penghasilan}

Dalam Undang-Undang Nomor 28 Tahun 2007 tentang Perubahan Ketiga Atas UndangUndang Nomor 6 Tahun 1983 Tentang Ketentuan Umum dan Tata Cara Perpajakan menyebutkan bahwa Orang pribadi atau badan yang telah ditetapkan oleh peraturan perpajakan yang berlaku di Indonesia merupakan subjek pajak. Subjek pajak Page | 51 
penghasilan adalah orang pribadi, warisan yang belum terbagi sebagai satu kesatuan menggantikan yang berhak, badan dan bentuk usaha tetap. Mereka semua yang termasuk ke dalam subjek pajak merupakan Wajib Pajak. Wajib Pajak adalah orang pribadi atau badan, meliputi pembayar pajak, pemotong pajak dan pemungut pajak yang mempunyai hak dan kewajiban perpajakan sesuai dengan ketentuan peraturan perundang-undangan perpajakan.

Menurut Undang-Undang Nomor 28 Tahun 2007 tentang Perubahan Ketiga Atas Undang-Undang Nomor 6 Tahun 1983 Tentang Ketentuan Umum dan Tata Cara Perpajakan menyebutkan bahwa yang menjadi objek pajak adalah penghasilan. Penghasilan yang dimaksud yaitu setiap tambahan kemampuan ekonomis yang diterima atau diperoleh Wajib Pajak, baik yang berasal dari Indonesia maupun dari luar Indonesia, yang dapat dipakai untuk konsumsi atau untuk menambah kekayaan Wajib Pajak yang bersangkutan, dengan nama dan dalam bentuk apapun. Penghasilan yang berasal dari transaksi pengalihan hak atas tanah dan/atau bangunan dikenai pajak penghasilan yang bersifat final.

\subsubsection{Pajak Penghasilan Atas Penghasilan Dari Pengalihan Hak Atas Tanah dan/atau Bangunan}

Pemajakan dalam bentuk presumptive tax sejatinya menggunakan metode tidak langsung dalam menghitung beban pajak yang terutang. Penggunaan kata presumptive yang berarti 'dugaan' mengacu pada asumsi bahwa besar penghasilan wajib pajak sebenarnya tidak lebih kecil dibandingkan jika menggunakan metode tidak langsung. (Thuronyi, 1996)

Dalam praktiknya, acuan presumptive yang digunakan sebagai landasan perhitungan agar mencerminkan basis pajak sebenarnya dapat berbasis pada indikator secara administratif dalam praktik di lapangan atau berbasis pada indikator yang ditetapkan dan diatur secara khusus dalam ketentuan pajak. (Tanzi dan de Jantscher, 1987)

Atas transaksi pengalihan hak atas tanah dan/atau bangunan dikenakan pajak penghasilan yang diatur dalam Peraturan Pemerintah Republik Indonesia Nomor 34 Tahun 2016 Tentang Pajak Penghasilan Atas Penghasilan dari Pengalihan Hak Atas Tanah dan/atau Bangunan, dan Perjanjian Pengikatan
Jual Beli Atas Tanah dan/atau Bangunan Beserta Perubahannya. Pajak Penghasilan atas transaksi tersebut dikenakan Pajak Penghasilan yang bersifat final. Berdasarkan Pasal 1 Ayat (1) PP Nomor 34 Tahun 2016 bahwa atas penghasilan yang diterima atau diperoleh orang pribadi atau badan dari pengalihan hak atas tanah dan/atau bangunan terutang Pajak Penghasilan Final. Besarnya tarif Pajak Penghasilan atas pengalihan hak atas tanah dan/atau bangunan $2,5 \%$ dari jumlah bruto nilai pengalihan hak atas tanah dan/atau bangunan selain pengalihan hak atas tanah dan/atau bangunan berupa Rumah Sederhana atau Rumah Susun Sederhana yang dilakukan oleh Wajib Pajak yang usaha pokoknya melakukan pengalihan hak atas tanah dan/atau bangunan.

\subsection{Teori Penilaian Properti}

\subsubsection{Pengertian Penilaian Properti}

Dalam melakukan Penilaian, Penilai di Indonesia memiliki pedoman yaitu Standar Penilaian Indonesia (SPI). Nilai sendiri merupakan sebuah opini dari manfaat ekonomi atas suatu kepemilikan aset yang ditetapkan pada waktu tertentu. Proses pekerjaan seorang Penilai dalam memberikan opini tertulis mengenai nilai ekonomi pada saat tertentu adalah Penilaian. Penilaian merupakan prakiraan manfaat ekonomi suatu barang yang dinilai pada satu ukuran waktu tertentu dengan definisi nilai yang tertentu pula (Sujono, 2011). Pengertian penilaian memiliki beberapa poin utama yaitu sebuah opini manfaat atas suatu aset berdasarkan data yang ada dan dilakukan pada satu waktu tertentu.

Dalam menjalankan tugasnya, Fungsional Penilai Pajak memiliki aturan terkait prosedur melakukan Penilaian, yaitu Surat Edaran Nomor SE-54/PJ/2016 Tentang Petunjuk Teknis Penilaian Properti, Penilaian Bisnis, dan Penilaian Aset Tak Berwujud Untuk Tujuan Pepajakan. Berdasarkan peraturan tersebut, Penilaian adalah serangkaian kegiatan untuk menentukan besaran suatu jenis nilai tertentu pada suatu waktu tertentu yang dilaksanakan secara objektif dan professional sesuai standar penilaian dalam rangka menjalankan ketentuan peraturan perundang-undangan perpajakan. Salah satu jenis Penilaian yaitu Penilaian Properti. Penilaian Properti merupakan Penilaian atas suatu konsep hukum yang mencakup kepentingan, hak dan manfaat atas 
suatu kepemilikan atas properti tersebut. Properti sendiri terbagi menjadi dua yaitu Real Properti dan Personal Properti. Tanah dan bangunan termasuk kedalam jenis Real Properti, sedangkan properti berwujud seperti mesin, peralatan, kendaran dan sebagainya tergolong kedalam Personal Properti.

\section{METODOLOGI}

\subsection{Metode Pengumpulan Data}

Metode penelitian yang digunakan adalah penelitian deskriptif kualitatif. Penelitian deskriptif merupakan penelitian untuk mencari fakta dengan interpretasi yang tepat (Whitney dalam Prihartono (2016). Tujuan dari penelitian adalah untuk membuat deskripsi, gambaran, maupun lukisan secara sistematis, faktual dan akurat mengenai fakta-fakta serta hubungan antara objek penelitian. Dalam menyusun dan menyelesaikan Karya Tulis Tugas Akhir ini penulis menggunakan beberapa metode untuk mengumpulkan, mengolah, dan menganalisis data, antara lain:

1. Metode studi kepustakaan

Metode studi kepustakaan berupa mempelajari berbagai buku refrensi maupun hasil penelitian yang telah dilakukan sebelumnya yang sejenis yang memiliki kegunaan untuk mendapatkan landasan teori mengenai masalah yang akan diteliti (Mirzaqon, 2018). Segala upaya yang dilakukan oleh penulis dalam menghimpun berbagai bahan pustaka yang relevan dengan topik permasalahan yang dibahas dari berbagai macam sumber tertulis baik cetak maupun elektronik merupakan sebuah bentuk studi kepustakaan(Djunaidi, 2017). Refrensi dalam studi kepustakaan yang diambil dari berbagai sumber dapat dijadikan sebagai informasi serta landasan teori dalam menyusun sebuah karya tulis.

\section{Metode Studi Lapangan}

Metode ini merupakan salah satu metode penelitian kualitatif. Penelitian kualitatif ini berusaha menemukan dan menggambarkan data yang ada secara naratif terkait kegiatan yang dilakukan serta dampak dari tindakan tersebut (Erikson dalam (Anggito \& Setiawan (2018). Salah satu teknik dalam metode studi lapangan yang digunakan adalah wawancara. Wawancara merupakan cara yang digunakan untuk memperoleh informasi melalui kegiatan interaksi social antara penliti dengan yang diteliti (Slamet dalam Edi (2016). Metode studi lapangan dalam penulisan KTTA ini merupakan metode yang dilakukan dengan cara pengamatan langsung terhadap proses penilaian dalam rangka pemeriksaan terhadap nilai wajar pasar atas pengalihan hak atas tanah dan/atau bangunan yang terjadi di KPP Pratama Metro.

\section{PEMBAHASAN}

\subsection{Proses Penilaian dalam Rangka Pemeriksaan Atas Penghasilan dari Pengalihan Hak Atas Tanah dan/atau Bangunan di KPP Pratama Metro sebelum terjadi pandemi COVID-19B. Pembahasan \\ Permintaan Tenaga Ahli guna menilai} kewajaran nilai pengalihan hak atas tanah dan/atau bangunan yang dilakukan oleh Wajib Pajak diajukan oleh Tim Pemeriksa Pajak. Hal ini berbeda dengan proses penelitian material dalam pemenuhan bukti kewajiban perpajakan atas penghasilan dari pengalihan hak atas tanah dan/atau bangunan yang dilakukan oleh Petugas Peneliti (AR Seksi Pengawasan dan Konsultasi II/III/IV atau Seksi Ekstensifikasi dan Penyuluhan). Transaksi atas pengalihan hak atas tanah dan/atau bangunan yang dilakukan oleh Wajib Pajak telah masuk kedalam proses pemeriksaan yang dilakukan oleh Tim Pemeriksa Pajak (Fungsional Pemeriksa) KPP Pratama Metro.

Menurut Ibu Nelly Eprillia, selaku salah satu anggota Tim Pemeriksa Pajak yang melakukan pemeriksaan terhadap Wajib Pajak mengatakan bahwa atas nilai tanah dan bangunan yang dilakukan pengalihan memiliki indikasi ketidakwajaran. Atas indikasi ketidakwajaran penghasilan dari transaksi pengalihan hak atas tanah dan/atau bangunan yang dikenakan PPh Final 4 ayat (2) merupakan salah satu transaksi atau data yang dapat dilakukan Penilaian. Berdasarkan hal tersebut, Tim Pemeriksa Pajak memutuskan untuk meminta bantuan tenaga ahli kepada Fungsional Penilai Pajak.

Atas permintaan bantuan Penilaian dalam rangka membantu pelaksanaan pemeriksaan tersebut, maka Fungsional Penilai Pajak dapat bertindak sebagai tenaga ahli untuk melakukan Penilaian terhadap pengalihan hak atas tanah dan/atau bangunan yang dilakukan oleh Wajib Pajak yang sedang dalam proses pemeriksaan. 
Dalam melaksanakan Penilaian, Fungsional Penilai Pajak membutuhkan dasar penugasan berupa Surat Tugas. Menurut keterangan yang terdapat pada Laporan Penilaian, Kepala KPP Pratama Metro telah menerbitkan Surat Tugas kepada Fungsional Pajak untuk melaksanakan Penilaian dalam rangka membantu pelaksanaan pemeriksaan. Hal ini telah sesuai dengan ketentuan yang berlaku. Surat Tugas yang dikeluarkan tersebut merangkap sebagai surat tugas peninjauan lapangan sekaligus Surat Tugas Membantu Pelaksanaan Pemeriksaan.

Berdasarkan keterangan narasumber, dasar hukum yang digunakan dan menjadi pedoman dalam melakukan Penilaian yang dilakukan oleh Fungsional Penilai Pajak di lingkup Direktorat Jenderal Pajak adalah Surat Edaran Direktur Jenderal Pajak Nomor SE54/PJ/2016 tentang Petunjuk Teknis Penilaian Properti, Penilaian Bisnis, dan Penilaian Aset Tak Berwujud Untuk Tujuan Perpajakan. Terdapat beberapa langkah proses Penilaian yang diatur dalam aturan tersebut yaitu sebagai berikut:

1. Identifikasi masalah meliputi penentuan tujuan Penilaian, penentuan dasar nilai, identifikasi objek penilaian, tanggal penilaian dan kondisi pembatas.

2. Pengumpulan dan pemilihan data.

3. Analisis data.

4. Pendekatan Penilaian.

5. Rekonsiliasi dan kesimpulan nilai.

6. Pelaporan Penilaian.

Langkah pertama dalam melakukan penilaian sesuai dengan ketentuan yang berlaku yaitu melakukan identifikasi masalah berupa penentuan tujuan Penilaian, penentuan dasar nilai, identifikasi objek penilaian, tanggal penilaian, asumsi dan kondisi pembatas. Berdasarkan data yang tercantum pada Laporan Penilaian, identifikasi masalah telah dilakukan oleh Fungsional Penilai Pajak. Penentuan tujuan Penilaian, penentuan dasar nilai, identifikasi objek penilaian, tanggal penilaian, asumsi dan kondisi pembatas telah dicantumkan dalam Laporan Penilaian.

Tujuan penilaian telah dicantumkan dalam Laporan Penilaian yaitu melaksanakan penilaian dalam rangka membantu pelaksanaan pemeriksaan. Hal ini juga sesuai dengan Sri Lestari et al (2019) bahwa tujuan Penilaian harus dinyatakan dengan jelas dalam Laporan Penilaian. Dasar nilai yang digunakan dalam
Penilaian telah ditentukan dan dicantumkan dalam Laporan Penilaian yaitu Nilai Pasar Wajar (Fair Market Value). Identifikasi Objek Penilaian juga telah dilakukan dan dicantumkan dalam Laporan Penilaian. Objek Penilaian berupa tanah dan bangunan yang terletak di tiga kawasan, yaitu Jalan Sutan Dumas Blok A, Jalan Sutan Dumas Blok B dan Jalan Mawar Komplek The Rose. Objek Penilaian terdiri dari sembilan belas (19) bidang tanah beserta bangunannya, dengan rincian Jalan Sutan Dumas Blok A sebanyak delapan (8) unit, Jalan Sutan Dumas Blok B sebanyak sembilan (9) unit dan Jalan Mawar Komplek The Rose sebanyak dua (2) unit. Tanggal penilaian telah ditetapkan dan dicantumkan dalam Laporan Penilaian yaitu pada tanggal saat transaksi dengan asumsi bahwa tidak terdapat perubahan sejak tanggal dilakukan penelitian di lapangan. Asumsi dan kondisi pembatas juga telah dicantumkan dalam Laporan Penilaian. Berdasarkan hal di atas, maka langkah pertama dalam proses penilaian di KPP Pratam Metro telah sesuai dengan ketentuan yang berlaku.

Langkah kedua yaitu pengumpulan dan pemilihan data. Berdasarkan keterangan dari narasumber, dalam mengumpulkan data pembanding Fungsional Penilai Pajak di KPP Pratama Metro menggunakan data dari sumber internal yang berasal dari Sistem Informasi Direktorat Jenderal Pajak. Data yang diperlukan dapat dimintakan kepada Seksi Pengolahan Data dan Informasi. Data tersebut berupa laporan bulanan yang disampaikan oleh Pejabat Pembuat Akta Tanah (PPAT) yang memuat Akta Jual Beli (AJB) yang didalamnya memuat keterangan transaksi pengalihan hak atas tanah yang dilakukan oleh Wajib Pajak. Berdasarkan Peraturan Pemerintah Republik Indonesia Nomor 34 Tahun 2016 Pasal 3 ayat (6) menyatakan bahwa Pejabat yang berwenang menandatangani akta, keputusan, kesepakatan, atau risalah lelang wajib menyampaikan laporan bulanan mengenai penerbitan akta, keputusan, kesepakatan, atau risalah lelang atas pengalihan hak atas tanah dan/atau bangunan. Apabila seorang PPAT tidak menyampaikan laporan bulanan akta atas pengalihan hak atas tanah dan/atau bangunan, maka dapat dikenai sanksi sesuai dengan ketentuan peraturan perundang-undangan. Data tersebut diberikan oleh Seksi Pengolahan Data dan Informasi kepada Fungsional Penilai

Page | 54 
Pajak berupa Alat Keterangan yang memuat tanggal data, nilai pengalihan, identitas penerima hak atau pembeli, nomor akta, nomor Sertifikat Hak Milik (SHM), letak tanah, luas tanah, NJOP tanah pada tahun pengalihan, nominal Surat Setoran Pajak beserta tanggal pembayarannya dan nominal Surat Setoran Bea (SSB) BPHTB.

Berdasarkan Alat Keterangan tersebut, Fungsional Penilai Pajak KPP Pratama Metro melakukan kunjungan lapangan (visit) ke lokasi Objek Penilaian. Fungsional Penilai Pajak KPP Pratama Metro menemui para pembeli sesuai dengan data yang tercantum pada Alat Keterangan dan mewawancarai mereka. Dari keterangan hasil wawancara kepada narasumber tersebut yang merupakan pembeli tanah dan bangunan yang menjadi Objek Penilaian, diketahui nominal nilai atas pembelian tanah dan bangunan tersebut.Berdasarkan keterangan dari Fungsional Penilai Pajak, wawancara tersebut hanya menghasilkan data yang dapat digunakan untuk Objek Penilaian yang terletak di Jalan Sutan Dumas Blok A dan Jalan Sutan Dumas Blok $B$, sedangkan untuk Objek Penilaian yang terletak di Jalan Mawar Komplek The Rose datanya didapatkan dari internet dan Akta Pengalihan Hak Tanggungan (APHT). Melihat hal di atas, maka langkah kedua dalam proses Penilaian yang dilakukan di KPP Pratama Metro telah sesuai dengan ketentuan yang berlaku.

Langkah ketiga yang dilakukan oleh Fungsional Penilai Pajak di KPP Pratama Metro adalah melakukan analisis terhadap data yang telah dikumpulkan sebelumnya. Analisis Nilai Pasar Wajar atas Objek Penilaian dibagi menjadi tiga sesuai dengan lokasi atau kawasan Objek Penilaian tersebut, sehingga hasil Penilaian berdasarkan data pembanding yang tersedia atas suatu tanah dan bangunan dalam satu lokasi atau kawasan dapat menjadi Nilai Pasar Wajar dari seluruh tanah dan bangunan dalam satu kawasan tersebut. Analisis Nilai Pasar Wajar atas Objek Penilaian dilakukan dengan menggunakan tiga data pembanding pada setiap lokasi Objek Penilaian. Terdapat beberapa asumsi terkait dengan analisa yang dilakukan yang telah dicantumkan dalam
Laporan Penilaian. Beberapa asumsi tersebut yaitu:

1. Bahwa tidak satu pun hal yang berkaitan dengan objek pajak disembunyikan yang mengakibatkan bertambah atau berkurangnya nilai. Penilai tidak bertanggung jawab atas rekayasa yang memungkinkan hal-hal yang ditutupi oleh Wajib Pajak.

2. Bahwa Penilaian telah dilaksanakan dengan mempertimbangkan seluruh batasan dan peraturan pemerintah yang berlaku dan melekat atas objek pajak, kecuali dinyatakan lain.

3. Bahwa peraturan mengenai peruntukan dan tata ruang atas objek pajak telah dipenuhi dan bila ada pengecualian telah dinyatakan dalam Laporan Penilaian.

Asumsi di atas merupakan beberapa asumsi terkait dengan Analisis Highest and Best Use (HBU) serta Analisis Pasar yang dilakukan oleh Fungsional Penilai Pajak dalam melakukan penilaian properti. Hal di atas telah sesuai dengan ketentuan yang berlaku dalam proses Penilaian.

Langkah keempat dalam menentukan nilai tanah dan bangunan dari Objek Penilaian adalah pendeketan penilaian. Berdasarkan keterangan dari narasumber dan data pada Laporan Penilaian, Fungsional Penilai Pajak di KPP Pratama Metro menggunakan Metode Pendeketan Data Pasar dalam penilaian ini. Pendekatan Data Pasar (Market Based Approach) menurut SE-54/PJ/2016 adalah pendekatan Penilaian yang menggunakan data transaksi atau penawaran atas properti yang sebanding dan sejenis dengan Objek Penilaian yang didasarkan pada suatu proses perbandingan dan penyesuaian.

Setelah didapatkan data atas harga pengalihan hak atas tanah dan bangunan dari lokasi Objek Penilaian, Fungsional Penilai Pajak KPP Pratama Metro melakukan penyesuaian terhadap data tersebut. Penyesuaian dilakukan pada jenis data dan waktu transaksi. Berikut ini adalah data nilai transaksi yang telah disesuaikan berdasarkan data yang didapatkan. 
Tabel Penyesuaian Data Pembanding

\begin{tabular}{|c|c|c|c|c|c|c|c|c|c|c|}
\hline \multirow[b]{2}{*}{$\begin{array}{l}\text { No } \\
\text { Data }\end{array}$} & \multirow[b]{2}{*}{ Lokasi Objek } & \multirow[b]{2}{*}{ Jenis Data } & \multicolumn{4}{|c|}{ Data Transaksi } & \multirow[b]{2}{*}{$\begin{array}{c}\text { Penyesuaian } \\
\text { Jenis Data }\end{array}$} & \multirow{2}{*}{$\begin{array}{c}\text { Perkiraan Nilai } \\
\text { Setelah } \\
\text { Penyesuaian } \\
\text { Jenis Data }\end{array}$} & \multirow[b]{2}{*}{$\begin{array}{c}\text { Penyesuaian } \\
\text { Waktu }\end{array}$} & \multirow[b]{2}{*}{$\begin{array}{l}\text { Nilai Setelah } \\
\text { Penyesuaian } \\
\text { Waktu }\end{array}$} \\
\hline & & & $\begin{array}{l}\text { Luas } \\
\text { Tanah }\end{array}$ & $\begin{array}{c}\text { Luas } \\
\text { Bangunan }\end{array}$ & $\begin{array}{l}\text { Tanggal } \\
\text { Penawaran }\end{array}$ & Harga & & & & \\
\hline 1 & $\begin{array}{c}\text { Jl Sutan Dumas } \\
\text { Blok B.13 }\end{array}$ & Jual Beli & 90 & 36 & $07 / 12 / 2016$ & Rp125.000.000 & $0 \%$ & Rp125.000.000 & $0 \%$ & Rp 125.000 .000 \\
\hline 2 & $\begin{array}{c}\text { Jl Sutan Dumas } \\
\text { Blok B.10 }\end{array}$ & Jual Beli & 90 & 36 & $02 / 12 / 2016$ & Rp125.000.000 & $0 \%$ & Rp125.000.000 & $0 \%$ & Rp 125.000 .000 \\
\hline 3 & $\begin{array}{c}\text { Jl Sutan Dumas } \\
\text { Blok A.13 }\end{array}$ & Jual Beli & 90 & 36 & $21 / 10 / 2016$ & Rp135.000.000 & $0 \%$ & Rp135.000.000 & $0 \%$ & Rp 135.000 .000 \\
\hline 4 & $\begin{array}{c}\text { Jl Sutan Dumas } \\
\text { Blok A. } 8\end{array}$ & Jual Beli & 90 & 36 & $21 / 10 / 2016$ & Rp135.000.000 & $0 \%$ & Rp135.000.000 & $0 \%$ & Rp 135.000 .000 \\
\hline 5 & $\begin{array}{c}\text { Jl Sutan Dumas } \\
\text { Blok A.10 }\end{array}$ & Jual Beli & 90 & 36 & $07 / 11 / 2016$ & Rp135.000.000 & $0 \%$ & Rp135.000.000 & $0 \%$ & Rp 135.000 .000 \\
\hline 6 & $\begin{array}{c}\text { Jl Mawar } \\
\text { Komp. The } \\
\text { Rose }\end{array}$ & Tanggungan & 90 & 60 & $26 / 10 / 2016$ & Rp268.750.000 & $0 \%$ & Rp268.750.000 & $0 \%$ & Rp 268.750 .000 \\
\hline 7 & $\begin{array}{l}\text { Jl Mawar } \\
\text { Komp. The } \\
\text { Rose }\end{array}$ & Penawaran & 90 & 60 & 03/09/2015 & Rp268.000.000 & $-5 \%$ & Rp254.600.000 & $26 \%$ & Rp 320.796 .000 \\
\hline 8 & $\begin{array}{l}\text { Jl Mawar } \\
\text { Komp. The } \\
\text { Rose }\end{array}$ & Penawaran & 90 & 60 & $27 / 03 / 2017$ & Rp350.000.000 & $-5 \%$ & Rp332.500.000 & $-10 \%$ & Rp 299.250.000 \\
\hline
\end{tabular}

Sumber: data diolah dari KPP Pratama Metro

Penyesuaian terhadap jenis data dan waktu atas data pembanding dilakukan dengan menggunakan asumsi yang telah ditetapkan oleh Fungsional Penilai Pajak KPP Pratama Metro. Atas data pembanding dengan jenis data jual beli tidak dilakukan penyesuaian. Menurut narasumber, hal ini disebabkan nilai pada data tersebut dianggap telah sesuai dengan keadaan pada saat terjadinya transaksi pengalihan hak, dimana kondisi jual beli atau transaksi telah terjadi dan harga tersebut telah disepakati oleh kedua belah pihak, baik penjual maupun pembeli. Besaran penyesuaian jenis data terhadap objek pembanding ditetapkan sebesar $-5 \%$ untuk jenis data penawaran. Asumsi yang digunakan adalah terjadi penurunan harga dari yang awalnya ditawarkan (penawaran) hingga disepakatinya harga atas transaksi pengalihan tanah dan bangunan tersebut (jual beli). Untuk penyesuaian waktu ditetapkan sebesar $2 \%$ perbulan untuk transaksi yang dilakukan pada tahun yang berbeda. Penyesuaian waktu dilakukan terhadap data pembanding yang terletak di Jalan Mawar Komplek The Rose dengan jenis data penawaran. Langkah keempat dalam proses Penilaian ini telah sesuai dengan Sri Lestari et al. (2019) yang menyatakan bahwa penilai menguraikan secara ringkas semua penilaian yang digunakan menggunakan pendekatan yang sesuai dengan tujuan penilaian dilakukan (dalam hal ini menggunakan Pendekatan Data Pasar).

Berdasarkan data di atas setelah dilakukan penyesuaian, maka untuk Objek Penilaian yang terletak di Jalan Sutan Dumas Blok A dan Jalan Sutan Dumas Blok B dapat ditetapkan Nilai Pasar Wajarnya. Hal ini merupakan langkah selanjutnya yaitu rekonsiliasi nilai dan kesimpulan nilai. Kedua hal tersebut telah tercantum dalam Laporan Penilaian. Objek Penilaian yang terletak di Jalan Sutan Dumas Blok A memiliki Nilai Pasar Wajar sebesar Rp135.000.000,00 dan yang terletak di Jalan Sutan Dumas Blok B memiliki Nilai Pasar Wajar sebesar Rp125.000.000,00. Untuk Objek Penilaian yang terletak di Jalan Mawar Komplek The Rose harus dilakukan perhitungan lebih lanjut terlebih dahulu karena nominal harga pada data pembanding di lokasi tersebut berbeda setiap datanya. Dalam menentukan Nilai Pasar Wajar terhadap Objek Penilaian yang terletak di Jalan Mawar Komplek The Rose, dilakukan penghitungan dengan menjumlahkan harga ketiga data pembanding tersebut, lalu dibagi tiga (sesuai dengan jumlah datanya). Melalui perhitungan tersebut maka didapatkan Nilai Pasar Wajar dari rata-rata nilai pada ketiga objek pembanding tersebut. Nilai Pasar Wajar atas Objek Penilaian yang terletak di Jalan Mawar Komplek The Rose sebesar Rp296.265.000,00. 
Tabel Nilai Pasar Wajar Objek Penilaian Jalan Mawar Komplek The Rose

\begin{tabular}{|c|c|c|c|c|c|c|c|}
\hline \multirow{2}{*}{$\begin{array}{l}\text { No. } \\
\text { Data }\end{array}$} & \multirow[b]{2}{*}{ Nilai/Unit } & \multicolumn{4}{|c|}{ Jenis Penyesuaian } & \multirow{2}{*}{$\begin{array}{c}\text { Total } \\
\text { Penyesuaian }\end{array}$} & \multirow[b]{2}{*}{ Nilai Pasar Wajar } \\
\hline & & Lokasi & Fisik & $\begin{array}{l}\text { Jenis } \\
\text { Hak } \\
\end{array}$ & Keluasan & & \\
\hline 1 & Rp 268.750.000 & $0 \%$ & $0 \%$ & $0 \%$ & $0 \%$ & $0 \%$ & $\mathrm{Rp} \quad 268.750 .000$ \\
\hline 2 & Rp 320.796.000 & $0 \%$ & $0 \%$ & $0 \%$ & $0 \%$ & $0 \%$ & Rp 320.796 .000 \\
\hline 3 & Rp 299.250.000 & $0 \%$ & $0 \%$ & $0 \%$ & $0 \%$ & $0 \%$ & Rp 299.250 .000 \\
\hline \multicolumn{7}{|c|}{ Nilai Pasar Wajar } & Rp 296.265 .333 \\
\hline \multicolumn{7}{|c|}{ Pembulatan } & Rp 296.265.000 \\
\hline
\end{tabular}

Sumber: data diolah dari KPP Pratama Metro

Sehingga berdasarkan Penilaian yang dilakukan oleh Fungsional Penilai Pajak KPP Pratama Metro atas Objek Penilaian tersebut menghasilkan kesimpulan nilai berupa Nilai Pasar Wajar sebagai berikut.

Tabel Nilai Pasar Wajar Objek Penilaian

\begin{tabular}{|c|c|c|c|c|c|}
\hline No & Uraian & Unit & & lai/Unit & Nilai Pasar Wajar \\
\hline 1. & Jl Sutan Dumas Blok A & 8 & $\mathrm{Rp}$ & 135.000 .000 & $\mathrm{Rp} \quad 1.080 .000 .000$ \\
\hline 2. & J1 Sutan Dumas Blok B & 9 & $\mathrm{Rp}$ & 125.000 .000 & Rp 1.125 .000 .000 \\
\hline 3. & Jl Mawar & 2 & $\mathrm{Rp}$ & 296.265 .000 & $\begin{array}{ll}\mathrm{Rp} & 592.530 .000 \\
\end{array}$ \\
\hline \multicolumn{5}{|c|}{ Jumlah } & Rp 2.797 .530 .000 \\
\hline
\end{tabular}

Sumber: data diolah dari KPP Pratama Metro

Berdasarkan data pada tabel di atas, didapatkan Nilai Pasar Wajar atas seluruh Objek Penilaian sebesar Rp2.797.530.000,00, maka potensi PPh Final 4 ayat (2) sebesar Rp69.938.250,00. Pada data yang diperoleh Tim Pemeriksa Pajak terdapat setoran PPh Final 4 ayat (2) yang telah disetorkan oleh Wajib Pajak sebesar Rp12.550.000,00. Hal tersebut menunjukan selisih PPh Final 4 ayat (2) antara yang seharusnya terhutang dengan yang telah dibayarkan oleh Wajib Pajak. Selisih PPh Final 4 ayat (2) sebesar Rp57.338.250,00 merupakan potensi penerimaan pajak atas Objek Penilaian tersebut. Langkah kelima yang telah dilakukan di atas telah sesuai dengan ketentuan yang berlaku. Kesimpulan nilai pada Laporan Penilaian juga telah ditandatangani oleh Fungsional Penilai Pajak yang melakukan proses Penilaian, dimana hal ini sesuai dengan Sri Lestari et al. (2019) bahwa kesimpulan nilai harus disertai tanda tangan asli dari penilai.

Langkah terakhir dari Penilaian tersebut adalah menuangkan seluruhnya dalam Laporan Penilaian Properti Kriteria I sesuai dengan format yang terdapat pada Surat Edaran Direktur Jenderal Pajak Nomor SE-54/PJ/2016 tentang Petunjuk Teknis Penilaian Properti, Penilaian Bisnis, dan Penilaian Aset Tak Berwujud Untuk Tujuan Perpajakan. Laporan tersebut diberikan kepada Kepala KPP Pratama Metro untuk disetujui dan ditandatangani untuk kemudian diteruskan kepada Tim Pemeriksa Pajak KPP Pratama Metro untuk dapat ditindaklanjuti. Laporan Penilaian yang dibuat oleh Fungsional Penilai Pajak di KPP Pratama Metro telah sesuai dengan ketentuan yang berlaku.

Berdasarkan seluruh uraian di atas, proses Penilaian yang dilakukan di KPP Pratama Metro telah sesuai dengan ketentuan yang berlaku. Setiap tahapan proses Penilaian yang dilakukan telah tercantum dalam Laporan Penilaian. Laporan Penilaian yang disampaikan juga telah sesuai dengan format yang diatur dalam ketentuan yang berlaku.

4.2. Proses Penilaian dalam Rangka
Pemeriksaan Atas Penghasilan dari
Pengalihan Hak Atas Tanah dan/atau
Bangunan di KPP Pratama Metro saat
terjadi pandemi COVID-19
Pandemi COVID-19 merupakan sebuah wabah penyakit yang merubah pola hidup manusia di seluruh dunia. Pandemi COVID-19 mulai masuk ke dalam wilayah Indonesia pada Maret 2020 dengan dikonfirmasinya dua pasien yang terinfeksi COVID-19. Sejak saat itu, Pemerintah berusaha menanggulangi pandemi COVID-19 dengan berbagai macam cara seperti 
Pembatasan Sosial Berskala Besar (PSBB), Pemberlakuan Pembatasan Kegiatan Masyarakat (PPKM) hingga pemberian vaksin. Hal ini tentunya berdampak pada kegiatan seluruh lapisan masyarakat baik pihak swasta maupun Pemerintah.

Dalam menjalankan tugas dan tanggung jawab yang dimilikinya, Direktorat Jenderal Pajak menerbitkan aturan terkait pelaksanaan kegiatan tugas yang dilakukan oleh para pegawainya selama masa pandemi COVID-19. Aturan terkait pelaksanaan tugas tersebut diatur dalam Surat Edaran Direktur Jenderal Pajak Nomor SE-34/PJ/2020 tentang Panduan Teknis Pelaksanaan Tugas Dalam Tatanan Kenormalan Baru di Lingkungan Direktorat Jenderal Pajak. Aturan tersebut dibuat dengan tujuan untuk memastikan pelaksanaan tugas dapat berjalan secara efektif serta memberikan panduan pelaksanaan tugas dalam beradaptasi dengan tatanan kenormalan baru.

Surat edaran tersebut juga memberikan panduan teknis penyesuaian pelaksanaan kegiatan tertentu di bidang penilaian. Beberapa panduan teknis penyesuaian kegiatan terkait dengan kegiatan di bidang penilaian yang diatur dalam aturan tersebut adalah sebagai berikut.

1. Penyampaian Surat Pemberitahuan Penilaian Pajak Bumi dan Bangunan.

2. Penyusunan Berita Acara Peninjauan Lapangan atau Surat Pernyataan Penolakan Peninjauan Lapangan Terkait Kegiatan Penilaian Nilai Jual Objek Pajak Bumi dan Bangunan.

3. Penyusunan Berita Acara Penolakan Peninjauan Lapangan Terkait Kegiatan Penilaian Nilai Jual Objek Pajak Bumi dan Bangunan.

4. Peminjaman Dokumen dan/atau Permintaan Salinan Dokumen, Daftar Dokumen yang dipinjam dan/atau Salinan Dokumen Terkait Kegiatan Penilaian Nilai Jual Objek Pajak Bumi dan Bangunan.

5. Permintaan Penjelasan Kepada Pihak Ketiga Terkait Kegiatan Penilaian Nilai Jual Objek Pajak Bumi dan Bangunan.

Berdasarkan hal di atas, terkait dengan penilaian dalam rangka pemeriksaan terhadap penghasilan yang berasal dari pengalihan hak atas tanah dan/atau bangunan dalam tatanan kenormalan baru tidak diatur dalam surat edaran tersebut. Hal ini juga dibenarkan oleh narasumber yaitu Bapak Rama Raditya selaku Fungsional Penilai Pajak di KPP Pratama Metro. Beliau mengatakan bahwa tidak terdapat aturan khusus yang mengatur terkait petunjuk teknis penilaian dalam rangka pemeriksaan terhadap penghasilan yang berasal dari pengalihan hak atas tanah dan/atau bangunan saat kondisi pandemi COVID-19. Namun, narasumber juga mengatakan terdapat sedikit perbedaan dalam melakukan penilaian dalam rangka pemeriksaan terhadap penghasilan yang berasal dari pengalihan hak atas tanah dan/atau bangunan saat pandemi COVID-19. Salah satu perbedaannya adalah ketika ingin mengumpulkan data dengan melakukan tinjauan langsung ke lapangan wajib memperhatikan protokol kesehatan yang ada.

Kondisi di lapangan yang memungkinkan terjadinya penyebaran COVID-19 saat melakukan proses Penilaian adalah ketika Fungsional Penilai Pajak mengumpulkan data dan terjadi interaksi sosial baik dengan Wajib Pajak atau sesama pegawai dalam satu kantor. Menurut narasumber, hal ini dikarenakan penyebaran COVID-19 yang semakin meningkat setiap harinya sehingga kunjungan ke lapangan menjadi lebih sulit dilakukan. Kondisi Wajib Pajak maupun lokasi objek penilaian atau objek pembanding yang memiliki sedikit informasi terkait dengan penyebaran COVID-19 menjadi salah satu pertimbangan mengapa kunjungan lapangan sulit dilakukan dalam masa pandemi seperti saat ini. Petugas tidak dapat mengetahui apakah Wajib Pajak dalam kondisi sehat dan tidak terjangkit COVID-19 atau sebaliknya. Petugas juga tidak dapat mengetahui apakah di lingkungan objek penilaian ataupun objek pembanding bebas dari penyebaran COVID-19 atau tidak.

Selain itu, kondisi kantor yang tidak dapat dipastikan juga menjadi faktor yang harus diperhatikan. Ketika dalam satu lingkup kantor terdapat pasien positif COVID-19 dengan status Orang Tanpa Gejala (OTG) maka dia dapat menyebarkan virus COVID-19 kepada pegawai lainnya. Apabila hal ini terjadi tentu dapat menghambat proses penilaian maupun kegiatan kantor dalam menjalankan tugas dan fungsinya. Menurut narasumber, walaupun telah dilakukan pemeriksaan rutin menggunakan tes SWAB maupun Rapid tetap 
terdapat kemungkinan penyebaran COVID-19 melalui sesama pegawai.

Protokol kesehatan yang wajib diperhatikan oleh petugas seperti selalu menggunakan masker ketika berinteraksi dengan Wajib Pajak, selalu membawa handsanitizer, dan menjaga jarak dengan orangorang di lapangan. Selain itu, petugas juga harus memperhatikan tingkat resiko penyebaran COVID-19 di wilayah yang akan dilakukan peninjauan lapangan serta menggunakan skala prioritas dengan mempertimbangkan potensi penerimaan atas objek penilaian tersebut.

Berdasarkan hal yang telah diuraikan di atas, dapat disimpulkan bahwa tidak terdapat perbedaan prosedur dalam melakukan penilaian dalam rangka pemeriksaan terhadap penghasilan yang berasal dari pengalihan hak atas tanah dan/atau bangunan dalam tatanan kenormalan baru. Namun, dalam pelaksanaan proses Penilaian saat ini petugas wajib memperhatikan protokol kesehatan yang ada agar terhindar dari penyebaran COVID-19.

4.3. Permasalahan dalam Proses Penilaian

Dalam Rangka Pemeriksaan Atas Penghasilan dari Pengalihan Hak Atas Tanah dan/atau Bangunan di KPP Pratama Metro sebelum terjadi pandemi COVID-19

Dalam pelaksanaan suatu proses pekerjaan tentunya akan ditemukan berbagai macam permasalahan dan kendala yang dihadapi. Proses Penilaian yang melibatkan kerja sama antara beberapa unit terkait dalam suatu kantor tentunya memiliki permasalahan dan kendala yang terjadi. Berdasarkan hasil analisa di lapangan terhadap proses Penilaian dalam rangka pemeriksaan terhadap Wajib Pajak yang melakukan transaksi pengalihan hak atas tanah dan bangunan dan wawancara dengan Fungsional Penilai Pajak di KPP Pratama Metro, diketahui terdapat beberapa permasalahan dan kendala yang terjadi. Permasalahan dan kendala yang terjadi di KPP Pratama Metro adalah sebagai berikut.

1. Belum maksimalnya permintaan bantuan Penilai terhadap beberapa kegiatan yang membutuhkan Penilaian oleh seksi lain.

Berdasarkan hasil wawancara dengan narasumber, masih minimnya permintaan bantuan Penilaian yang diterima oleh Fungsional Penilai Pajak menjadi salah satu permasalahan yang sering terjadi di KPP.
Permintaan bantuan Penilai Pajak sebagai Tenaga Ahli dalam Pemeriksaan atau dari seksi lain di lingkungan KPP sebagai pemicu Penilaian masih belum dilakukan secara optimal. Narasumber juga mengatakan bahwa Fungsional Penilai Pajak KPP Pratama Metro hanya beberapa kali menerima permohonan permintaan bantuan Penilain dari seksi lainnya. Tanpa terjadinya pemicu Penilaian, maka Penilai Pajak tidak dapat melakukan Penilaian.

Menurut Surat Edaran Direktur Jenderal Pajak Nomor SE-05/PJ/2020 tentang Prosedur Pelaksanaan Penilaian Untuk Tujuan Perpajakan Huruf E Angka 2, terdapat transaksi atau data yang seharusnya memerlukan Penilaian seperti jumlah yang seharusnya dikeluarkan atau diterima dalam hal jual beli harta yang dipengaruhi hubungan istimewa, harga pasar dalam hal tukar menukar harta atau pengalihan harta dalam rangka likuidasi, penggabungan, peleburan, pemekaran, pemecahan, atau pengambilalihan usaha, harga pasar wajar dalam hal penyerahan Barang Kena Pajak (BKP) atau Jasa Kena Pajak (JKP) yang dipengaruhi hubungan istimewa atau harga limit dalam lelang barang hasil sitaan. Atas dasar aturan tersebut, seharusnya peran Penilai Pajak yang berada di KPP dapat lebih dioptimalkan.

2. Surat Tugas Membantu Pelaksanaan Pemeriksaan yang dirangkap dengan surat tugas kunjungan ke lapangan.

Dalam melakukan Penilaian guna membantu pelaksanaan pemeriksaan terhadap Wajib Pajak yang melakukan transaksi pengalihan hak atas tanah dan bangunan, Fungsional Penilai Pajak KPP Pratama Metro mendapatkan Surat Tugas yang merangkap antara Surat Tugas Membantu Pelaksanaan Pemeriksaan dan Surat Tugas dalam rangka kunjungan lapangan. Hal tersebut memang tidak dilarang dalam aturan terkait dengan prosedur pelaksanaan Penilaian, tetapi lebih baik apabila kedua surat tugas tersebut tidak digabung menjadi satu. Hal ini juga diakui oleh narasumber selaku Fungsional Penilai Pajak. Beliau mengatakan bahwa memang lebih baik Surat Tugas tersebut dipisah agar proses administrasi di kemudian hari menjadi lebih mudah apabila terjadi sesuatu yang melibatkan dokumen tersebut.

Pemisahan surat tugas tersebut dapat membuat proses administrasi dan penatausahaan dokumen akan menjadi lebih 
baik dikemudian harinya ketika Laporan Penilaian tersebut dibutuhkan. Surat Tugas Membantu Pelaksanaan Pemeriksaan merupakan dasar Penilaian yang dilakukan oleh Penilai Pajak yang bertindak sebagai Tenaga Ahli dalam proses pemeriksaan, sedangkan surat tugas untuk kunjungan lapangan merupakan surat tugas tambahan apabila Penilai Pajak memerlukan peninjauan lapangan. Atas dasar hal tersebut, seharusnya yang menjadi dasar utama yang dibutuhkan oleh Penilai Pajak dalam melakukan Penilaian tersebut adalah Surat Tugas Membantu Pelaksanaan Pemeriksaan.

3. Pemeriksaan terhadap transaksi pengalihan hak atas tanah dan/atau bangunan seharusnya dapat diproses dalam Penelitian Material oleh Account Representative.

Menurut keterangan Ibu Nelly Eprillia selaku anggota Tim Pemeriksa Pajak dalam proses Penilaian yang telah dijelaskan sebelumnya, atas pemeriksaan yang dilakukan oleh Tim Pemeriksa Pajak terhadap indikasi ketidakwajaran dalam nilai pengalihan hak atas tanah dan bangunan yang dilakukan Wajib Pajak, seharusnya dapat dilakukan oleh AR menggunakan mekanisme Penelitian Materal dalam rangka pemenuhan bukti kewajiban perpajakan. Apabila atas transaksi pengalihan hak atas tanah dan bangunan tersebut dinilai memiliki indikasi ketidakwajaran, AR dapat mengajukan permohonan bantuan Penilaian ketika melakukan Penelitian Material saat membuat Laporan Hasil Penelitian (LPHt).

Berdasarkan keterangan di lapangan dan hasil wawancara dengan narasumber, memang diakui bahwa AR memiliki beban kerja yang cukup banyak dan berat sehingga hal tersebut terkadang tidak terdeteksi dalam pengawasan mereka. Namun, apabila dalam Penelitian Material dapat dilakukan dengan baik maka hal tersebut dapat terselesaikan tanpa harus memasuki proses pemeriksaan dan Tim Pemeriksa Pajak dapat melakukan pemeriksaan terhadap Wajib Pajak lainnya.

4.4. Permasalahan dalam Proses Penilaian Dalam Rangka Pemeriksaan Atas Penghasilan dari Pengalihan Hak Atas Tanah dan/atau Bangunan di KPP Pratama Metro saat pandemi COVID-19

Pandemi COVID-19 menjadi masalah bagi seluruh negara di dunia dan setiap negara berusaha mencari cara untuk menghadapi situasi tersebut. Situasi seperti ini tentu memberikan masalah baru dalam berbagai aspek kegiatan seluruh pihak baik Pemerintah maupun swasta. Direktorat Jenderal Pajak dalam mengantisipasi pandemi COVID-19 mengeluarkan SE-34/PJ/2020 sebagai panduan teknis dalam pelaksanaan tugas bagi para pegawainya dalam situasi tata kenormalan baru. Salah satu bidang pelaksanaan tugas yang diberikan panduan teknis dalam aturan tersebut adalah bidang penilaian. Terkait dengan bidang penilaian yang diatur dalam aturan tersebut adalah seputar nilai jual objek Pajak Bumi dan Bangunan dan tidak mengatur terkait pelaksanaan penilaian dalam rangka pemeriksaan.

Namun, proses penilaian dalam rangka pemeriksaan atas penghasilan yang berasal dari pengalihan hak atas tanah dan/atau bangunan di KPP Pratama Metro saat pandemi COVID-19 tentu memiliki hambatan tersendiri. Berdasarkan hasil keterangan dari wawancara dengan Fungsional Penilai Pajak di KPP Pratama Metro, bahwa salah satu hambatan dalam menjalankan tugas penilaian dalam rangka pemeriksaan saat pandemi COVID-19 yaitu terbatasnya pergerakan ketika ingin mencari data langsung dari lapangan. Protokol kesehatan memiliki aturan ketat yang harus dipatuhi oleh petugas ketika berinteraksi dengan Wajib Pajak sehingga tidak semudah ketika belum terjadi pandemi COVID-19.

Dalam proses penilaian tentu tidak jarang bagi Fungsional Penilai Pajak untuk harus melakukan kunjungan ke lapangan guna mencari data terkait dengan objek penilaian. Kondisi pandemi COVID-19 membuat interaksi sosial menjadi terbatas yaitu dengan diharuskannya setiap orang untuk melakukan pembatasan sosial. Wajib Pajak atau pihak terkait dalam hal ini tentu menjadi lebih sulit untuk ditemui dengan alasan menjaga interaksi sosial guna pencegahan penyebaran COVID-19. Menurut narasumber, kendala ini menyebabkan pengumpulan data di lapangan menjadi terhambat. Selain dengan sulitnya ditemui Wajib Pajak yang berkaitan dengan objek penilaian, kondisi Wajib Pajak yang tidak dapat diketahui oleh petugas juga menjadi pertimbangan dalam melakukan kunjungan ke lapangan. Berdasarkan keterangan narasumber, pada kondisi pandemi seperti ini 
petugas tidak dapat mengetahui apakah Wajib Pajak yang ditemui dalam kondisi sehat atau telah terinfeksi COVID-19. Selain kondisi tersebut, kondisi wilayah objek penilaian atau objek pembanding juga tidak dapat dipastikan apakah bebas dari penyebaran COVID-19 atau tidak. Ketika petugas memutuskan melakukan kunjungan ke lapangan, maka kondisi kesehatan mereka yang dapat terancam. Menurut narasumber, hal ini menjadi salah satu bentuk resiko pekerjaan dalam situasi pandemi seperti ini.

Pembatasan jumlah pegawai yang bekerja di kantor juga menjadi hambatan bagi Fungsional Penilai Pajak dalam melaksanakan penilaian dalam rangka pemeriksaan. Menurut keterangan hasil dari wawancara dengan narasumber, kunjungan lapangan dalam rangka mengumpulkan data terkait dengan objek penilaian maupun objek pembanding menjadi tidak mudah dilakukan karena hanya dapat dilakukan pada saat petugas mendapat giliran bekerja di kantor (Work From Office). Kegiatan kunjungan ke lapangan tidak dapat dilakukan oleh Fungsional Penilai Pajak apabila petugas berada dalam jadwal bekerja dari rumah (Work From Home). Kunjungan ke lapangan yang sebelumnya dapat dilakukan kapanpun selama hari kerja, saat ini menjadi terbatas dikarenakan terdapat jadwal yang mengharuskan pegawai bekerja dari kantor atau bekerja dari rumah. Hal ini sesuai dengan pernyataan dari narasumber yang mengatakan bahwa pengumpulan data terkait dengan objek penilaian maupun objek pembanding menjadi terhambat dan membutuhkan waktu lebih lama dibandingkan kondisi ketika sebelum terjadi pandemi COVID19.

\section{SIMPULAN DAN SARAN}

\subsection{Simpulan}

Penilaian untuk tujuan perpajakan merupakan salah satu upaya yang dilakukan oleh Direktorat Jenderal Pajak guna meningkatkan penerimaan perpajakan. Salah satu objek pajak yang memerlukan adanya Penilaian adalah PPh Final Pasal 4 Ayat (2) atas penghasilan yang Wajib Pajak terima dari pengalihan hak atas tanah dan/atau bangunan. Berdasarkan penjelasan yang telah dipaparkan sebelumnya, maka dapat ditarik kesimpulan sebagai berikut:
1. Pelaksanaan proses penilaian dalam rangka pemeriksaan terhadap nilai wajar pasar atas pengalihan hak atas tanah dan/atau bangunan di KPP Pratama Metro sebelum terjadi pandemi COVID-19 telah sesuai dengan peraturan yang berlaku. Hal tersebut dibuktikan dengan:

a. Penggunaan Nota Dinas dari Tim Pemeriksa Pajak kepada Fungsional Penilai Pajak berupa permintaan bantuan tenaga ahli untuk melakukan penilaian terhadap objek PPh Final Pasal 4 ayat (2) yang terindikasi memiliki nilai pasar yang tidak sewajarnya.

b. Kepala KPP Pratama Metro menerbitkan Surat Tugas sesuai dengan prosedur yang berlaku kepada Fungsional Penilai Pajak sebagai bentuk tindak lanjut Nota Dinas Permintaan bantuan tenaga ahli dari Tim Pemeriksa Pajak.

c. Fungsional Penilai Pajak telah melakukan penilaian sesuai dengan aturan yang berlaku dengan menggunakan pendekatan data pasar dan membuat laporan penilaian sesuai dengan ketentuan yang berlaku.

2. Pelaksanaan proses penilaian dalam rangka pemeriksaan terhadap nilai wajar pasar atas pengalihan hak atas tanah dan/atau bangunan di KPP Pratama Metro saat kondisi pandemi COVID-19 tidak berbeda dengan proses penilaian saat kondisi sebelum terjadi pandemi COVID-19. Perbedaan yang terjadi terletak pada penerapan protokol kesehatan saat petugas akan melakukan kunjungan ke lapangan guna mengumpulkan data terkait dengan objek penilaian.

3. Terdapat beberapa permasalahan dalam proses penilaian dalam rangka pemeriksaan atas penghasilan dari pengalihan hak atas tanah dan/atau bangunan di KPP Pratama Metro sebelum terjadi pandemi COVID-19. Beberapa permasalahan tersebut seperti belum maksimalnya permintaan bantuan Penilai terhadap beberapa kegiatan yang membutuhkan Penilaian oleh seksi lain, Surat Tugas Membantu Pelaksanaan Pemeriksaan yang dirangkap dengan surat tugas kunjungan ke lapangan, dan pemeriksaan terhadap transaksi pengalihan hak atas tanah 
dan/atau bangunan seharusnya dapat diproses dalam Penelitian Material oleh Account Representative sehingga tidak sampai pada tahap pemeriksaan oleh Fungsional Pemeriksa Pajak.

4. Permasalahan yang terjadi dalam proses penilaian dalam rangka pemeriksaan atas penghasilan dari pengalihan hak atas tanah dan/atau bangunan di KPP Pratama Metro saat kondisi pandemi COVID-19 yaitu dengan diterapkannya protokol kesehatan yang harus dipatuhi petugas dalam melaksanakan tugasnya terutama ketika akan melakukan kunjungan ke lapangan guna mengumpulkan data terkait dengan objek penilaian. Hal ini membuat pengumpulan data terkait dengan objek penilaian menjadi terhambat dan membutuhkan waktu lebih lama dibandingkan kondisi ketika sebelum terjadi pandemi COVID19.

\subsection{Solusi}

Melihat permasalahan dan kendala yang terjadi di atas, tentu terdapat solusi yang dapat dilakukan agar permasalahan dan kendala tersebut dapat diatasi. Solusi tersebut tentunya juga diharapkan mampu membuat unit kerja menjadi lebih baik dan lebih optimal dalam menjalankan tugas dan fungsinya. Berdasarkan hasil analisa yang dilakukan oleh Penulis, terdapat beberapa solusi yang dapat dilakukan sebagai berikut.

1. Melakukan Pendekatan Kepada Unit/Seksi Terkait.

Penilai Pajak dapat melakukan pendekatan kepada unit terkait untuk memberitahukan beberapa data atau transaksi yang membutuhkan atau mengharuskan adanya Penilaian. Hal ini dapat dilakukan dengan menyebarkan form pertanyaan kepada AR, Juru Sita maupun Tim Pemeriksa Pajak. Form pertanyaan tersebut dapat berisi pertanyaan seperti apakah terdapat transaksi atau data yang dilakukan oleh Wajib Pajak yang dapat dilakukan Penilaian yang berada dalam pengawasan AR atau pemeriksaan Tim Pemeriksa Pajak atau terdapat barang sitaan yang akan dilelang oleh Juru Sita. Ketika hasil dari form pertanyaan yang telah disebarkan tersebut menyatakan bahwa terdapat transaksi atau data tersebut, maka Penilai Pajak dapat melakukan pendekatan kepada unit terkait dengan mengatakan bahwa transaksi atau data yang mereka punya dapat dilakukan Penilaian dan terdapat potensi penerimaan pajak didalamnya.

Dengan pendekatan yang telah dilakukan, diharapkan unit terkait membuat nota dinas permintaan bantuan Penilaian agar Penilaian dapat dilaksanakan. Penilai Pajak dalam hal ini berusaha membuat terjadinya pemicu Penilaian agar Penilaian tersebut dapat dilakukan. Tanpa adanya pemicu Penilaian, maka Penilai Pajak tentu tidak memiliki dasar penilaian sehingga proses Penilaian tidak dapat dilakukan. Potensi penerimaan pajak dari hasil Penilaian terkadang masih belum dapat dipahami oleh beberapa pihak, sehingga dibutuhkan peran aktif dari Penilai Pajak itu sendiri untuk menyosialisasikan hal tersebut.

2. Memisahkan Surat Tugas Membantu Pelaksanaan Pemeriksaan dengan surat tugas kunjungan ke lapangan.

Dalam melaksanakan Penilaian dalam rangka membantu pemeriksaan, dapat dibuatkan Surat Tugas Membantu Pelaksanaan Pemeriksaan tersendiri. Hal ini yang akan dijadikan dasar dalam melakukan Penilaian oleh Penilai Pajak. Apabila dalam proses berjalannya Penilaian membutuhkan kunjungan lapangan, Penilai Pajak dapat mengajukan permohonan untuk diterbitkannya surat tugas kunjungan ke lapangan oleh Kepala Kantor. Dengan demikian maka akan tercipta admnistrasi dan penatausahaan dokumen yang lebih baik. Selain hal tersebut, hal ini tentunya sebagai bentuk antisipasi apabila dikemudian hari terdapat permasalahan hukum dan Penilaian dianggap tidak sesuai prosedur oleh Wajib Pajak. Tidak sedikit kekalahan pihak Direktorat Jenderal Pajak dalam pengadilan akibat kesalahan terkait dengan proses yang tidak sesuai dengan SOP.

3. Memisahkan fungsi konsultasi dari tugas yang dimiliki oleh AR Seksi Pengawasan dan Konsultasi II/III/IV dan berfokus kepada fungsi pengawasan.

4. Beban tugas yang dimiliki oleh AR pada Seksi Pengawasan dan Konsultasi II/III/IV dinilai cukup berat. Selain harus melakukan pengawasan terhadap Wajib Pajak, mereka juga memiliki tugas untuk menangani permasalahan yang dihadapi oleh Wajib Pajak. Hal ini merupakan fungsi AR sebagai pihak yang menangani konsultasi dari Wajib Pajak. Memisahkan fungsi konsultasi tersebut diharapkan mampu menurunkan beban kerja yang dimiliki AR. Fungsi konsultasi dapat 
difokuskan kepada Seksi Pengawasan dan Konsultasi I yang bertugas sebagai Help Desk dan AR bagi Seksi Pelayanan. Hal tersebut masih sejalan dengan tugas dan fungsi yang mereka jalankan. Diharapkan dengan berkurangnya beban kerja tersebut, maka AR dapat lebih

\section{DAFTAR PUSTAKA}

Anggito, A., \& Setiawan, J. (2018). Metodologi Penelitian Kualitatif. CV Jaya.

Djunaidi. (2017). Sumber Rujukan Sebagai Referensi yang Mendukung Karya Tulis Ilmiah Bagi Pustakawan. Jurnal Kepustakawanan Dan Masyarakat, 33(2), 1-11.

Edi, F. R. S. (2016). Teori Wawancara Psikodiagnostik. PT Leutika Nouvalitera.

Ellryz, R., \& Suryandono, W. (2019). Peran Notaris Dalam Mencegah Wajib Pajak Melakukan Tax Avoidance Melalui Manipulasi Hibah. Universitas Indonesia.

Ferbiana, W. (2016). Pengaruh Pelayanan Pajak Kesadaran Wajib Pajak Dan Pengetahuanperpajakan Terhadap Kepatuhan Wajib Pajak Dalam Membayar Pajak Bumi Dan Bangunan Di Kecamatan Ilir Barat li (Dua) Kota Palembang Sumatera Selatan (Vol. 42, Issue 1).

Kosasih, A. (2019). Ketahui Perbedaan Mendasar Pajak Penghasilan (PPh) Final dan Tidak Final. Klikpajak. https://klikpajak.id/blog/pajakbisnis/pph-final-dan-tidak-final/

M Riza Aufa Rahman. (2020). Efektivitas Pasal 1 Peraturan Direktur Jendral Pajak Nomor PER-18/PJ/2017. Jurnal Hukum Dan Kenotariatan, 4(1), 134-145.

Mirzaqon, A. (2018). Studi Kepustakaan Mengenai Landasan Teori Dan Praktik Konseling Expressive Writing Library. Jurnal BK UNESA, 1, 1-8.

Prihartono, A. W. (2016). Surat Kabar \& Konvergensi Media (Studi Deskriptif Kualitatif Model Konvergensi Media Pada Solopos). CHANNEL: Jurnal Komunikasi, 4(1), 105-116.

Sri Lestari, V. N., Cahyono, D., \& Susanto, O. A. (2019). Perlunya Penilaian Properti pada Kantor Jasa Penilai Publik. Journal fokus dalam melakukan pengawasan salah satunya terkait dengan Penelitian Material atas indikasi ketidakwajaran nilai terhadap bukti pemenuhan kewajiban perapajakan atas penghasilan dari pengalihan hak atas tanah dan bangunan yang dilakukan oleh Wajib Pajak.

Community Development and Society, 1(1), 20-33.

Sujono, B. (2011). Penilaian Asset Dalam Sektor Properti. Modul, 11(1), 37-40.

Wicaksono, P. (2018). Prosedur Verifikasi Pajak Penghasilan Final Atas Pengalihan Hak Atas Tanah dan/atau Bangunan di Kantor Pelayanan Pajak Pratama Pati. In Laporan Magang. 